American Journal of Clinical and Experimental Medicine
2016; 4(3): $43-49$
http://www.sciencepublishinggroup.com/j/ajcem
doi: 10.11648 /j.ajcem.20160403.12
ISSN: $2330-8125$ (Print); ISSN: $2330-8133$ (Online)

\title{
In vivo Efficacy of Ethanolic Extract of Cassia nigricans (Vahl) Against Gastro-Intestinal Nematodes (GIN) of Goats in West Nile Region, Uganda
}

\author{
Peter Oba $^{1,}$, , Denis Asizua ${ }^{1}$, Godwin Komuntaro ${ }^{1}$, Nasser Kasozi ${ }^{1}$, Moses Kalenzi ${ }^{1}$, \\ Michael Apamaku ${ }^{1}$, John Kateregga ${ }^{2}$, James Okwee-Acai ${ }^{2}, J^{\prime m m y ~ G . ~ N d u k u i ~}{ }^{2}$, William Kabasa ${ }^{3}$, \\ Katali K. Benda ${ }^{4}$ \\ ${ }^{1}$ National Agricultural Research Organization, Abi Zonal Agricultural Research and Development Institute, Arua, Uganda \\ ${ }^{2}$ Department of Pharmacy, Clinical and Comparative Medicine, College of Veterinary Medicine, Animal Resources and Biosecurity, \\ Makerere University, Kampala, Uganda \\ ${ }^{3}$ Department of Biotechnical and Diagnostic Sciences, College of Veterinary Medicine, Animal Resources and Biosecurity, Makerere \\ University, Kampala, Uganda \\ ${ }^{4}$ National Agricultural Research Organization, Kachwekano Zonal Agricultural Research and Development Institute, Kabale, Uganda
}

\author{
Email address: \\ dobaat2@gmail.com (P. Oba), asizua@gmail.com (D. Asizua), komuntarogodwin@yahoo.com (G. Komuntaro), \\ kasonax@yahoo.com (K. Nasser), kalenzi.moses@yahoo.com (M. Kalenzi),mike_apamaku@yahoo.com (M. Apamaku), \\ katereggaj@covab.mak.ac.ug(J. Kateregga),jokwee@yahoo.co.uk (J. Okwee-Acai),ndukuiga@gmail.com (J. G. Ndukui), \\ kabasawm@gmail.com (W.W. Kabasa),katalibenda@gmail.com (K. K. Benda) \\ *Corresponding author
}

\section{To cite this article:}

Peter Oba, Denis Asizua, Godwin Komuntaro, Nasser Kasozi, Moses Kalenzi, Michael Apamaku, John Kateregga, James Okwee-Acai, Jimmy G. Ndukui, William Kabasa, Katali K. Benda. In vivo Efficacy of Ethanolic Extract of Cassia nigricans (Vahl) Against GastroIntestinal Nematodes (GIN) of Goats in West Nile Region, Uganda. American Journal of Clinical and Experimental Medicine. Vol. 4, No. 3, 2016, pp. 43-49. doi: 10.11648/j.ajcem.20160403.12

Received: March 28, 2016; Accepted: April 11, 2016; Published: April 27, 2016

\begin{abstract}
Several plants are used by farmers for the treatment of gastrointestinal nematodes (GIN) in goats. However, their phytochemical properties, efficacy and safety is largely unknown. A trial was therefore designed to determine in vivo efficacy of ethanolic extract of Cassia nigricans against gastrointestinal nematodes (GIN) in goats. Cassia nigricans leaves were collected from Arua District, Uganda. Ethanolic extraction method was to prepare extracts and the experimental goats were dosed accordingly. Treatments were assigned to five (5) groups of goats $(\mathrm{n}=9)$ as follows: Group A, the negative control $(30 \mathrm{ml}$ of distilled water; group B, the positive control (Albendazole 10\%, $8 \mathrm{mg} / \mathrm{kg}$ ). Groups C, D and E received extracts at 50, 100 and $150 \mathrm{mg} / \mathrm{kg}$, respectively. Live weights (LWs kg), faecal samples (for faecal egg count reduction (FECR) based on eggs per gram (EPGs) of faeces, packed cell volume (PCV \%), total protein (TP g/dL), body condition scores (1-5) and Faffa Malan Chart (FAMACHA scores 1-5) were taken on day 1 of the experiment and subsequently at 7-day intervals for 4 weeks. Results revealed that a significant increase in LWs by $2^{\text {nd }}$ week was observed in goats treated with Albendazole from $20.8 \pm 1.9$ to $21.9 \pm 1.8$ ( $\mathrm{p} \leq$ $0.05)$. No change in LWs and in TP was observed in all other groups $(\mathrm{p} \geq 0.05)$. Only Albendazole treated group exhibited a significant increase of PCV in the $2^{\text {nd }}$ week $(p \leq 0.05)$. EPGs were observed to significantly drop in those treated with Albendazole by the $2^{\text {nd }}$ week from $300 \pm 91$ to $0 \pm 0$ and extract at $150 \mathrm{mg} / \mathrm{kg}$ dose from $740 \pm 236$ to $60 \pm 25(\mathrm{p} \leq 0.05)$. The FECR for Albendazole, 50, 100 and $150 \mathrm{mg} / \mathrm{kg}$ doses of the extract were found to be $100 \%, 37.3 \%, 66.6 \%$ and $83.8 \%$ respectively. Only at $150 \mathrm{mg} / \mathrm{kg}$ dose did the extract show moderate efficacy in reducing mixed Strongyle spp faecal egg counts in goats. Strongyles spp. were the most predominant genera of nematodes found in goats. Further evaluations of leaf extracts and other plant parts is necessary to establish its potential as a source of local effective remedy against gastro-intestinal nematodes in goats.
\end{abstract}

Keywords: Ethnoveterinary, Medicine, Cassia nigricans, Gastro-Intestinal, Nematodes, West Nile 


\section{Introduction}

Studies reveal that farmers use several plants for management of livestock and human diseases [1]. Different plant species are efficacious in the control of parasite infestations in livestock and are promising alternatives to conventional anthelmintics [1-3]. However, the phytochemical properties, efficacy and safety of these plant medicinal remedies have not been scientifically validated. The problem of drug resistance by internal parasites has become a serious constraint to small ruminant production in the tropics [2]. In order to improve goat productivity, alternative local options for control and treatment of endemic nematode infections is justified as conventional drugs have become expensive or ineffective [3].

A tropical herbaceous shrub, Cassia nigricans (Vahl, Etiringu in Lugbara; family: Leguminosae) in West Nile region is commonly used for treatment of gastro-intestinal nematodes (GIN) in goats. Cassia species are known to be rich sources of anthraquinone derivatives, polyphenols and flavonoids [4]; emodin glycosides and emodic acid. C. nigricans is known to be the secondary source of metabolites, notably anthraquinone derivatives [6], alkaloids and tannins. Condensed tannins have been shown to have effects against several gastrointestinal (GI) parasites in animals $[5,6]$. A related plant, Cassia sieberiana is confirmed to have anthelmintic activity against Haemonchus contortus [7]. Though Cassia nigricans is commonly used against GIN in goats, its efficacy is presently unknown. It is against this background that this study was formulated to determine in vivo efficacy of ethanolic leaf extract of Cassia nigricans against gastro-intestinal nematodes (GIN) in goats.

\section{Materials and Methods}

\subsection{Collection and Preparation of Plant Extract}

The plant leaves were collected from Arua in West Nile region in May 2014, placed in a polythene bag and submitted to the Department of Botany, Makerere University. The plant was authenticated at the Department of Botany herbarium as Cassia nigricans (Vahl) with voucher specimen number as OB001 (Fig 1). The leaves were then transferred to Makerere University College of Veterinary Medicine, Department of Pharmacy, Clinics and Comparative Medicine laboratory for processing. The fresh leaves were cleaned by use of running tap water to remove dust and debris. Thereafter, the leaves were open air dried under a shade to a constant weight for one week period. After drying the leaves were pulverized into a fine powder using an electrical grinder. A weight of $500 \mathrm{~g}$ of the powder was cold macerated into 2 litres of $70 \%$ ethanol placed into 2.5 ltr Erlen Meyer's bottle. The soaked mixture was twice daily vigorously shaken for $72 \mathrm{hrs}$ and kept in a locked cabinet away from direct light. After $72 \mathrm{hrs}$, the mixture was filtered, with the filtrate concentrated by use of rotary evaporator (CH-9230 Flawl/Scwel) [8]. The World Association for the Advancement of Veterinary Parasitology (WAAVP) dose determination guidelines were followed [9]. Using the WAAVP dose determination guidelines, 50, 100 and $150 \mathrm{mg} / \mathrm{kg}$ doses were computed and used to dose the animals. The volume of extract administered for the in vivo efficacy trial was calculated using the equation:

$$
\text { Volume }(m l s)=\frac{\text { dose }\left(\frac{\mathrm{mg}}{\mathrm{kg}}\right) \times \text { live weight }(\mathrm{kg})}{\text { Stock concentration }\left(\frac{\mathrm{mg}}{\mathrm{ml}}\right)}
$$

\subsection{Selection and Management of Goats}

Forty five (45) healthy goats were selected from Abi Zonal Agricultural Research and Development Institute, Arua in May, 2014. The goats were reared on natural pastures at the institute and given water ad libitum during the trial. Both males and female goats were selected and identified with ear tags and colored strings. The goats were grazed at the institute's pastures and allowed to acquire natural infection. All treated animals were observed daily for any health complications during the trial.

\subsection{Study Design and Administration of Treatments}

A blocked, randomized, controlled trial was conducted as follows: A total of 45 goats were selected based on 3 age groups and randomly allocated to different treatments as shown in Table 1. Each group of goats was given treatment as follows: Group A received $30 \mathrm{ml}$ of distilled water per goat (negative control); Group B received Albendazole 10\% (Norbrook $^{\circledR}$ Ltd, Nairobi, Kenya) at manufacturer's dosage rate of $8 \mathrm{mg} / \mathrm{kg} \mathrm{b}$. wt.; Group C received extract at $50 \mathrm{mg} / \mathrm{kg}$ b.wt; Group D received extract at $100 \mathrm{mg} / \mathrm{kg} \mathrm{b}$. wt. and Group E received extract at $150 \mathrm{mg} / \mathrm{kg}$ b. wt. All treatments were administered orally using a $20 \mathrm{ml}$ plastic syringe.

Table 1. Treatment groups by age of goats (months).

\begin{tabular}{|c|c|c|c|c|c|c|}
\hline \multirow{2}{*}{$\begin{array}{l}\text { Age group } \\
\text { (months) }\end{array}$} & \multicolumn{5}{|c|}{ Treatment groups (mg/kg b. wt.) } & \multirow{2}{*}{ Totals } \\
\hline & A: Distilled water & B: Albendazole 10\% & C: Extract $50 \mathrm{mg} / \mathrm{kg}$ & D: Extract $100 \mathrm{mg} / \mathrm{kg}$ & E: Extract $150 \mathrm{mg} / \mathrm{kg}$ & \\
\hline $4-7$ & 3 & 3 & 3 & 3 & 2 & 14 \\
\hline $8-12$ & 3 & 3 & 4 & 4 & 4 & 18 \\
\hline $13-18$ & 2 & 3 & 3 & 2 & 3 & 13 \\
\hline Total & 8 & 9 & 10 & 9 & 9 & 45 \\
\hline
\end{tabular}

$\mathrm{n}=45$; Ordinary water (Negative control); Albendazole 10\% (Positive control) 


\subsection{Data Collection}

Live body weights, Faecal egg counts (FEC, eggs per gram), FAMACHA scores, body condition scores (BCS) and blood samples were taken from all the goats on day 1 and thereafter at 7-day intervals (day 8, day 15 and day 22) post treatment. Live body weights ( $\mathrm{LW}, \mathrm{kg}$ ) were measured using a Hanson ${ }^{\mathrm{TM}}$ spring balance (MFRSH Enterprises, India). Blood samples were collected from the jugular vein using $\mathrm{BD}^{\circledR}$ plastic EDTA and $\mathrm{BD}^{\circledR}$ plain Vacutainer ${ }^{\circledR}$ tubes (BD Hemogard) for determination of packed cell volume $(\mathrm{PCV}, \%)$ and total protein $(\mathrm{TP}, \mathrm{g} / \mathrm{dL})$ respectively. TP was determined using a Goldberg Refractometer (Reichert, $\mathrm{GmbH}$ ) (a total solids meter) because of its convenience and high accuracy. The blood was centrifuged at $2000 \mathrm{rpm}$ for determination of $\mathrm{PCV}$ using a microhematocrit reader (BIOFUGE Haemo, Germany). FAMACHA scores, based on a $1-5$ scoring index ranging from $1=$ reddish (normal) to $5=$ white (critically anaemic) were determined [10].

Faecal samples were taken from all goats for determination of egg counts (eggs per gram of faeces, EPGs) [11]. Faecal samples were taken directly from the rectum of each goat using gloved hands into $10 \mathrm{ml}$ labeled plastic containers and placed in ice box $\left(5^{\circ} \mathrm{C}\right)$. They were immediately (within 24 hrs.) transported to the College of Veterinary Medicine Parasitology laboratory for screening using a modified McMaster technique, with a sensitivity of 50 EPGs [11].

The efficacy of each treatment was determined by computing the percent faecal egg count reduction test (FECRT) using the following formula [12]

$$
\text { FECRT }=\left\{1-\left[\frac{\mathrm{T}_{\mathrm{a}} \times \mathrm{C}_{\mathrm{b}}}{\mathrm{T}_{\mathrm{b}} \times \mathrm{C}_{\mathrm{a}}}\right]\right\} \times 100
$$

$\mathrm{T}$ and $\mathrm{C}$ represent arithmetic means of EPGs in treatment and negative control groups and subscripts $\mathrm{b}$ and a denote counts before and after treatment respectively. Faecal samples collected were pooled and used to identify helminthes to genus level, using a Baerman's technique $[11,13]$.

\subsection{Data Analysis}

The FECR was calculated from only individuals that tested positive by the McMaster technique. Data recorded weekly for 4 consecutive weeks was entered using Excel 16.0. R statistical analysis software (Version 3.2.0) was used for generation of statistical measures. The effects of the different treatments on blood parameters and EPGs were compared between weeks. Mean EPGs of different treatment groups were compared with a negative control. Analysis of variance (ANOVA) was used to examine treatment differences at $95 \%$ confidence interval.

\section{Results}

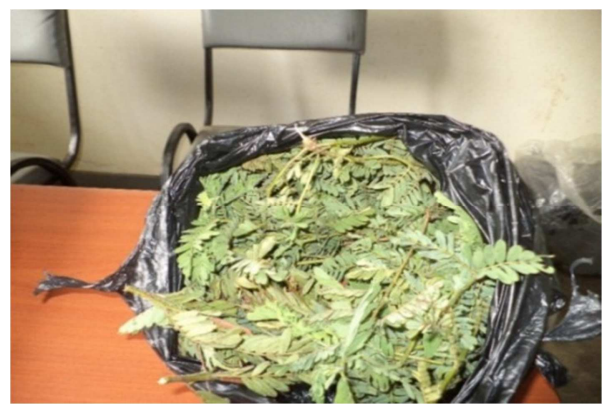

Figure 1. Fresh leaf sample of Cassia nigricans.

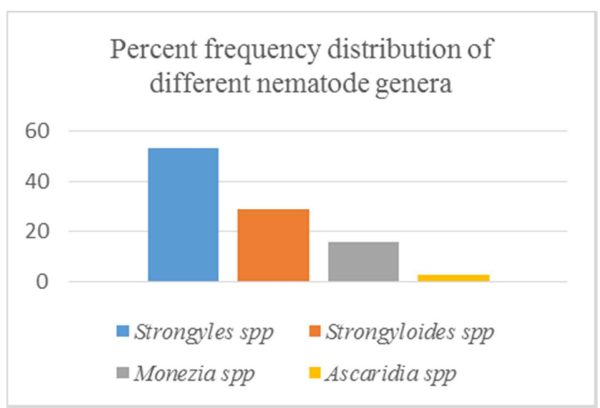

Figure 2. Distribution of nematode genera found in goats.

Table 2 below shows there was a significant drop in LWs $(\mathrm{p} \leq 0.05)$ in those treated with distilled water from the $3^{\text {rd }}$ to $4^{\text {th }}$ week. Albendazole treated group showed a significant increase $(p \leq 0.05)$ in LWs in the $2^{\text {nd }}$ week. However, a marginal increase $(p \geq 0.05)$ in live body weights was observed in those treated with extract at $100 \mathrm{mg} / \mathrm{kg}$ dose by $2^{\text {nd }}$ week of the trial. A significant reduction in LWs was recorded in goats treated with extract at $150 \mathrm{mg} / \mathrm{kg}$ dose in the $3^{\text {rd }}$ week of the trial $(p \leq 0.05)$. Although not significant, a marginal increase in mean live weights was recorded in those treated with Albendazole by the $4^{\text {th }}$ week of the trial. However, a marginal increase $(p \leq 0.05)$ in live body weights was observed in those treated with extract at $100 \mathrm{mg} / \mathrm{kg}$ in the $2^{\text {nd }}$ week of the trial.

Table 2. Variation of mean live body weights $(\mathrm{kg})$ at weekly intervals.

\begin{tabular}{|c|c|c|c|c|}
\hline \multirow{2}{*}{ Treatment } & \multicolumn{4}{|c|}{ Live body weights (kg) } \\
\hline & Week 1 & Week 2 & Week 3 & Week 4 \\
\hline Distilled water & $16.37 \pm 1.93^{\mathrm{a}}$ & $16.78 \pm 2.04^{\mathrm{a}}$ & $15.66 \pm 1.85^{b}$ & $15.68 \pm 1.93^{\mathrm{b}}$ \\
\hline Albendazole $10 \%$ & $20.87 \pm 1.97^{\mathrm{b}}$ & $21.96 \pm 1.84^{\mathrm{a}}$ & $20.87 \pm 1.80^{\mathrm{b}}$ & $22.06 \pm 2.07^{\mathrm{a}}$ \\
\hline Extract $50 \mathrm{mg} / \mathrm{kg}$ & $25.18 \pm 1.52^{\mathrm{a}}$ & $26.00 \pm 1.65^{b}$ & $24.80 \pm 1.64^{\mathrm{a}}$ & $25.06 \pm 1.54^{\mathrm{a}}$ \\
\hline Extract $100 \mathrm{mg} / \mathrm{kg}$ & $16.12 \pm 2.78^{\mathrm{a}}$ & $18.06 \pm 3.03^{\mathrm{a}}$ & $16.18 \pm 2.67^{\mathrm{a}}$ & $16.62 \pm 2.74^{\mathrm{a}}$ \\
\hline Extract $150 \mathrm{mg} / \mathrm{kg}$ & $21.82 \pm 1.77^{\mathrm{a}}$ & $21.06 \pm 1.68^{\mathrm{a}}$ & $19.87 \pm 1.62^{\mathrm{b}}$ & $20.56 \pm 1.66^{\mathrm{a}}$ \\
\hline
\end{tabular}

Results expressed as Mean \pm SEM. Similar superscripts $a, b$, in the same row show no statistical difference ( $p \geq 0.05$ ); different superscripts in the same row shows statistical difference $(\mathrm{p} \leq 0.05)$ 
We found a significant treatment group effect $(\mathrm{F}=3.53$; $\mathrm{p}$ $=0.015)$ in mean LWs between $50 \mathrm{mg} / \mathrm{ml}$ extract and a negative control. Similarly, there was a significant treatment group difference in LWs between $50 \mathrm{mg} / \mathrm{kg}$ and $100 \mathrm{mg} / \mathrm{kg}$ extracts $(\mathrm{p} \leq 0.05)$.

No significant change $(\mathrm{p} \geq 0.05)$ in total protein $(T P)$ was observed in all treatment groups in the $2^{\text {nd }}$ week (Table 3 ). However, TP significantly declined from the $3^{\text {rd }}$ to $4^{\text {th }}$ week in all treated groups $(\mathrm{p} \leq 0.05)$. There was a significant drop in TP $(\mathrm{p} \leq 0.05)$ in the negative control group from the $2^{\text {nd }}$ to $4^{\text {th }}$ week (Table 3$)$.

Table 3. Variation of mean total protein (TP, $g / d L)$ at weekly intervals.

\begin{tabular}{|c|c|c|c|c|}
\hline \multirow{2}{*}{ Treatment } & \multicolumn{4}{|c|}{ Total protein (TP, g/dL) } \\
\hline & Week 1 & Week 2 & Week 3 & Week 4 \\
\hline Distilled water & $6.72 \pm 0.22^{\mathrm{a}}$ & $5.97 \pm 0.20^{b}$ & $5.55 \pm 0.26^{\mathrm{b}}$ & $5.70 \pm 0.30^{\mathrm{b}}$ \\
\hline Albendazole $10 \%$ & $6.65 \pm 0.17^{\mathrm{a}}$ & $6.37 \pm 0.21^{\mathrm{a}}$ & $5.55 \pm 0.16^{\mathrm{b}}$ & $5.87 \pm 0.13^{b}$ \\
\hline Extract $50 \mathrm{mg} / \mathrm{kg}$ & $6.85 \pm 0.10^{\mathrm{a}}$ & $6.77 \pm 0.21^{\mathrm{a}}$ & $6.15 \pm 0.24^{\mathrm{b}}$ & $5.95 \pm 0.10^{\mathrm{b}}$ \\
\hline Extract $100 \mathrm{mg} / \mathrm{kg}$ & $6.45 \pm 0.35^{\mathrm{a}}$ & $6.17 \pm 0.25^{\mathrm{a}}$ & $6.00 \pm 0.32^{\mathrm{b}}$ & $5.90 \pm 0.20^{\mathrm{b}}$ \\
\hline Extract $150 \mathrm{mg} / \mathrm{kg}$ & $6.35 \pm 0.26^{\mathrm{a}}$ & $6.05 \pm 0.22^{\mathrm{a}}$ & $5.75 \pm 0.17^{\mathrm{b}}$ & $6.17 \pm 0.10^{\mathrm{a}}$ \\
\hline
\end{tabular}

Results expressed as Mean \pm SEM. Similar superscripts $a, b$, in the same row show no statistical difference $(p \geq 0.05)$; different superscripts in the same row shows statistical difference $(\mathrm{p} \leq 0.05)$.

PCV significantly increased $(p \leq 0.05)$ in the second week in the group treated with Albendazole (Table 4). In the groups treated with ethanolic extract at 50 and $100 \mathrm{mg} / \mathrm{kg}$ doses, we observed a significant drop $(\mathrm{p} \leq 0.05)$ in PCV, but was seen to rise again in the $3^{\text {rd }}$ week. However, no change in PCV ( $p \geq 0.05)$ was noted in those treated with the extract at $150 \mathrm{mg} / \mathrm{kg}$ dose throughout the experiment.

Table 4. Variation of mean packed cell volume (PCV, \%) at weekly intervals.

\begin{tabular}{|c|c|c|c|c|}
\hline \multirow{2}{*}{ Treatment } & \multicolumn{4}{|c|}{ Packed cell volume (PCV, \%) } \\
\hline & Week 1 & Week 2 & Week 3 & Week 4 \\
\hline Distilled water & $35.12 \pm 1.18^{\mathrm{a}}$ & $31.37 \pm 0.77^{\mathrm{a}}$ & $34.25 \pm 1.25^{\mathrm{a}}$ & $31.37 \pm 1.22^{\mathrm{b}}$ \\
\hline Albendazole $10 \%$ & $31.00 \pm 1.25^{\mathrm{a}}$ & $34.37 \pm 1.23^{\mathrm{b}}$ & $34.62 \pm 1.55^{\mathrm{b}}$ & $31.37 \pm 1.32^{\mathrm{a}}$ \\
\hline Extract $50 \mathrm{mg} / \mathrm{kg}$ & $36.50 \pm 1.29^{\mathrm{a}}$ & $31.50 \pm 1.01^{\mathrm{b}}$ & $37.12 \pm 1.61^{\mathrm{a}, \mathrm{c}}$ & $33.25 \pm 0.95^{\mathrm{a}}$ \\
\hline Extract $100 \mathrm{mg} / \mathrm{kg}$ & $35.75 \pm 1.53^{\mathrm{a}}$ & $31.62 \pm 0.99^{b}$ & $37.12 \pm 1.61^{\mathrm{a}}$ & $33.00 \pm 0.96^{\mathrm{c}}$ \\
\hline Extract $150 \mathrm{mg} / \mathrm{kg}$ & $33.00 \pm 1.58^{\mathrm{a}}$ & $31.37 \pm 1.48^{\mathrm{a}}$ & $32.75 \pm 1.16^{\mathrm{a}}$ & $29.75 \pm 1.35^{\mathrm{a}}$ \\
\hline
\end{tabular}

Results expressed as Mean $\pm \mathrm{SEM}$; similar superscripts $a, b, c$, in the same row show no statistical difference $(\mathrm{p} \geq 0.05)$; different superscripts in the same row shows statistical difference $(\mathrm{p} \leq 0.05)$

Table 5 below shows there was a significant increase of EPGs $(p \leq 0.05)$ in goats treated with water from the first to the $3^{\text {rd }}$ week. A significant reduction in EPGs $(p \leq 0.01)$ was observed in those treated with Albendazole from the first to third week. Similarly, a significant drop $(\mathrm{p} \leq 0.01)$ in EPGs was observed in the group treated with ethanolic extract at 100 $\mathrm{mg} / \mathrm{kg} \mathrm{b}$. wt. up to the $3^{\text {rd }}$ week of the experiment. A sharp increase in EPGs was observed in the group treated with extract at $100 \mathrm{mg} / \mathrm{kg}$ by the $4^{\text {th }}$ week of the trial. The group treated with the extract at $150 \mathrm{mg} / \mathrm{kg} \mathrm{b}$. wt. exhibited a significant reduction in EPGs during the $2^{\text {nd }}$ week of the trial $(\mathrm{p} \leq 0.05)$, but which sharply rose during the $3^{\text {rd }}$ and $4^{\text {th }}$ week.

Table 5. Variation of mean faecal egg counts, FEC (EPGs) at weekly intervals.

\begin{tabular}{lllll}
\hline \multirow{2}{*}{ Treatment } & \multicolumn{2}{l}{ Faecal egg counts (EPGs) } & & Week 3 \\
\cline { 2 - 5 } & Week 1 & Week 2 & $287.5 \pm 111.0^{\mathrm{a}}$ & $112.5 \pm 48^{\mathrm{a}}$ \\
\hline Distilled water & $200 \pm 0^{\mathrm{a}}$ & $100 \pm 0^{\mathrm{b}}$ & $162.5 \pm 50.0^{\mathrm{a}}$ & $325 \pm 70^{\mathrm{a}}$ \\
Albendazole $10 \%$ & $300 \pm 91^{\mathrm{a}}$ & $0 \pm 0^{\mathrm{b}}$ & $387.5 \pm 252.0^{\mathrm{a}}$ & $200 \pm 94.5^{\mathrm{a}}$ \\
Extract $50 \mathrm{mg} / \mathrm{kg}$ & $533 \pm 145^{\mathrm{a}}$ & $167 \pm 167^{\mathrm{a}}$ & $275.0 \pm 195.0^{\mathrm{a}}$ & $600 \pm 264^{\mathrm{a}}$ \\
Extract $100 \mathrm{mg} / \mathrm{kg}$ & $300 \pm 200^{\mathrm{a}}$ & $50 \pm 50^{\mathrm{b}}$ & $25.0 \pm 25.0^{\mathrm{b}}$ & $650 \pm 173^{\mathrm{a}}$ \\
Extract $150 \mathrm{mg} / \mathrm{kg}$ & $740 \pm 236^{\mathrm{a}}$ & $60 \pm 25^{\mathrm{b}}$ & \\
\hline
\end{tabular}

Results expressed as Mean \pm SEM; similar superscripts $a, b$, in the same row show no statistical difference $(p \geq 0.05)$; different superscripts in the same row shows statistical difference $(\mathrm{p} \leq 0.05)$

Table 6 below showed that the ethanolic extract at 50 $\mathrm{mg} / \mathrm{kg}$ had a FECR of $37.3 \%$, while at $100 \mathrm{mg} / \mathrm{kg}$ dose, the FECR was found to be $66.6 \%$ implying lack of, or limited efficacy against GIT nematodes. The Kruskal-Wallis rank sum test did not show a significant difference in median
FAMACHA scores in all treatment groups throughout the 4 week experimental period ( $\mathrm{p} \geq 0.05$ ). Although not found to be significant $(p=0.406)$, those treated with Albendazole showed a slight improvement in median BCS. 
Table 6. Percent mean faecal egg count reduction (FECR).

\begin{tabular}{llll}
\hline Treatment group & EPGs Baseline (pre-treatment) & EPGs (Day 8) (post treatment) & FECR \% \\
\hline Distilled water & $200 \pm 0^{\mathrm{a}}$ & $100 \pm 0^{\mathrm{b}}$ & 0 \\
Albendazole $10 \%$ & $300 \pm 91^{\mathrm{a}}$ & $0 \pm 0^{\mathrm{b}}$ & 0.3087 \\
Extract $50 \mathrm{mg} / \mathrm{kg}$ & $533 \pm 145^{\mathrm{a}}$ & $167 \pm 167^{\mathrm{a}}$ & $0.046^{*}$ \\
Extract $100 \mathrm{mg} / \mathrm{kg}$ & $300 \pm 200^{\mathrm{a}}$ & $50 \pm 50^{\mathrm{b}}$ & 0.3414 \\
Extract $150 \mathrm{mg} / \mathrm{kg}$ & $740 \pm 236^{\mathrm{a}}$ & $60 \pm 25^{\mathrm{b}}$ & 0.6508 \\
\hline
\end{tabular}

Values of EPGs expressed as Mean $\pm \mathrm{SEM} ;{ }^{*} \mathrm{p} \leq 0.05$ statistically significant

\section{Discussion}

Lack of a significant change in LWs gains in all treatment groups, except Albendazole treated group is probably due to limited effect of the extracts on LWs. A group treated with extract at $150 \mathrm{mg} / \mathrm{kg}$ dose rate showed a significant drop in LWs in the $3^{\text {rd }}$ week, suggesting a possible negative effect on LWs. This is in agreement with toxicity of Cassia species at high doses reported by [6]. Albendazole treated group exhibited a significant increase in PCV in the $2^{\text {nd }}$ week, but no difference was observed until the $4^{\text {th }}$ week of the trial. This is expected as Albendazole showed complete efficacy against GIN nematodes. This suggests that anemia can be used as a reliable clinical feature for worm infestation in goats. The PCV of goats treated with extracts at 50 and 100 $\mathrm{mg} / \mathrm{kg}$ concentration dropped significantly during the $2^{\text {nd }}$ week and rapidly rose in the $3^{\text {rd }}$ week of the trial. This could probably be due to delayed release of active phytochemicals in the extract. A similar observation was made for TP in the group treated with extract at $150 \mathrm{mg} / \mathrm{kg}$ dose.

For a drug to be considered efficacious, a minimum of $90 \%$ fecal egg reduction is required [14]. A standard of $70 \%$ fecal egg reduction for ethnoveterinary drugs was proposed [15]. Achieving a $70 \%$ fecal egg reduction requires that animals should be predominantly infected with Haemonchus contortus [3]. In this study, we observed a significant reduction in EPGs in the groups treated with Albendazole, extract at $100 \mathrm{mg} / \mathrm{kg}$ and extract at $150 \mathrm{mg} / \mathrm{kg}$ concentration (Table 5). This reduction was more pronounced with increasing concentration of the extract, suggesting a dosedependent relationship.

The ethanolic extract at $50 \mathrm{mg} / \mathrm{kg}$ showed a faecal egg count reduction (FECR) of $37.3 \%$, while at $100 \mathrm{mg} / \mathrm{kg}$ concentration, the FECR was found to be $66.6 \%$ implying lack of, or limited efficacy against GIT nematodes (Table 6). The results revealed that the percent FECR increased with increasing extract concentration. At a higher extract concentration $(150 \mathrm{mg} / \mathrm{kg})$, the faecal egg count reduction (83.8\%) was above the $70 \%$ minimum standard set for ethnoveterinary drugs. This is also slightly above the $80 \%$ moderate efficacy standard set by WAAVP guidelines [9]. This suggests, at this concentration, the ethanolic extract of $C$. nigricans was moderately efficacious in reducing the worm burden in goats. This agrees with previous studies, which showed Cassia nigricans possesses pharmacologically bioactive compounds (flavonoids, emodic acid, tannins and anthraquinones) useful for the prophylaxis and therapy of several human and livestock parasitic diseases [6]. Cassia species are well known for their laxative and purgative properties [16], gastro-intestinal, anthelmintic activities [23, 24] and are known to occur as pharmacologically active constituents of many cathartics. In addition to the phytochemical compounds present in Cassia nigricans [6], this laxative property of the plant extract could be responsible for its ability to reduce the faecal egg counts in goats. However, caution should be taken in their use at higher doses because of negative effects, as shown by weight loss at $150 \mathrm{mg} / \mathrm{kg}$ dose rate.

Albendazole exhibited a significant reduction in EPGs in the second week, but EPGs were observed to rise in the $3^{\text {rd }}$ week, probably due to re-infection of the goats, as the drug is eliminated from the gut. However, the percent FECR for Albendazole was $100 \%$, signifying complete efficacy against GIN in goats. This is comparable to the FECR of 95\% [17] and 99.34\% [18] in Southern Ethiopia, 99\% in Kanungu [19], but higher than the $77.3 \%$ reported by [20]. The ethanolic extract of C. nigricans at $150 \mathrm{mg} / \mathrm{kg}$ dose rate was able to significantly reduce EPGs in the $3^{\text {rd }}$ week, suggesting a prolonged effect after oral administration.

Efficacy of plant products against GIN parasites is affected by several factors. The concentrations of bioactive phytochemicals in the plant has been shown to vary by harvest season, origin, drying processes and plant parts used. A seasonal variation occurs in the concentration of anthraquinones in $C$. nigricans, with peak concentrations observed during the dry season [21]. The plant sample was collected during the rainy season and this could have influenced the concentration of bioactive phytochemicals in the plant. The methods of preparation, storage and the concentrations used, could be different from those used by traditional healers. Our study used extraction method described by [22], as opposed to the paste formulation used by traditional healers. Besides, the dose used by the traditional healers could be different from that used in this study and this could account for the variation in efficacy of the plant extracts against GI nematodes. This study therefore provides useful information on the potential dosage rate of $C$. nigricans as a local anthelmintic in goats.

We observed no significant differences in median FAMACHA scores in all treatment groups throughout the 4 week experimental period. Similarly, median BCS did not show any significant differences between treated and control groups throughout the trial. This study revealed that Strongyles spp. were the most predominant genera of 
nematodes found in goats, followed by Strongyloides spp (Fig 2). Monezia spp and Ascarids were of minor importance.

\section{Conclusions and Recommendations}

i. This study revealed that the leaf ethanolic extract of Cassia nigricans at $150 \mathrm{mg} / \mathrm{kg}$ concentration was moderately efficacious in reducing GIT nematode faecal egg counts in goats. At lower dose rates (50 and 100 $\mathrm{mg} / \mathrm{kg}$ ), the ethanolic extract of Cassia nigricans lacked efficacy against GIT nematodes.

ii. Albendazole showed complete efficacy (100\%) against GIT nematodes in goats.

We recommend further studies using different concentrations of the extract and on other parts of the plant (bark, roots) to establish its potential as a source of local effective remedy against gastro-intestinal nematodes in goats

\section{Acknowledgements}

The authors wish to thank NARO through Agricultural Technology and Advisory Services (ATAAS) project for funding the study and the Director of Research, Abi ZARDI for supporting the study.

\section{References}

[1] Nalule A, Mbaria J, Olila D, Kimenju J. Ethnopharmacological practices in management of livestock helminthes by pastoral communities in the dry lands of Uganda. Livestock Research for Rural Development. 2011; 23(2).

[2] Waller P. Sustainable nematode parasite control strategies for ruminant livestock by grazing management and biological control. Animal Feed Science and Technology. 2006;126 (34): $277-89$.

[3] Githiori J, Höglund J, Waller P, Leyden B. Evaluation of anthelmintic properties of extracts from some plants used as livestock dewormers by pastoralist and smallholder farmers in Kenya against Heligmosomoides polygyrus infections in mice. Vet Parasitol. 2003;118 (3-4): 215-26.

[4] Ayo R, Amupitan J, Ndukwe I, Audu O. Some chemical constituents of the leaves of Cassia nigricans, Vahl African Journal of Pure and Applied Chemistry. 2009 3(11): 208-11.

[5] Athanasiadou S, Kyriazakis I, Jackson F, Coop R. Direct anthelmintic effects of condensed tannins towards different gastrointestinal nematodes of sheep: in vitro and in vivo studies. Veterinary Parasitology. 2001; 99: 205-19.

[6] Ayo RG. Phytochemical constituents and bioactivities of the extracts of Cassia nigricans Vahl: A review. Journal of Medicinal Plants Research. 2010;4(14): 1339-48.

[7] Diehl M, Kamanzi Atindehou K, Tere H, Betschart B. Prospect for anthelmintic plants in the Ivory Coast using ethnobotanical criteria. Journal of Ethnopharmacology. 2004. 95: 277-84.

[8] Ndukui J, Okwee-Acai J, Kateregga J. Methods of medicinal plants extract preparation. 2013 (unpublished).
[9] Wood I, Amaral NK, Bairden K, Duncan JL, Kassai T, Malone Jr, JB., Pankavich, JA., Reinecke, RK., Slocombe, O., Taylor, SM., Vercruysse, J. World Association for the Advancement of Veterinary Parasitology (W.A.A.V.P) second edition of guidelines for evaluating efficacy of anthelmintics in ruminants (bovine, ovine, caprine). Vet Parasitol. 1995 (58)181-213.

[10] van Wyk JA, Bath GF. The FAMACHA system for managing haemonchosis in sheep and goats by clinically identifying individual animals for treatment. Vet. Res. 2002; 33(5): pp. 509-29.

[11] Coles G, Bauer C, Borgsteede F, Geerts S, Klei T, Taylor M, Waller PJ. World Association for the Advancement of Veterinary Parasitology (WAAVP) methods for the detection of anthelmintic resistance in nematodes of veterinary importance. Vet Parasitol. 1992; 44: pp. 35-44.

[12] Dash K, Hall E, Barger I. The role of arithmetic and geometric mean worm egg count reduction tests and in monitoring strategic drenching programs in sheep. Aus. Vet. Journal. 1988(62):66-8.

[13] Ministry of Food, Agriculture and Forestry. Manual of Veterinary Parasitological Laboratory Techniques, Technical Bulletin No 18. Great Britain1971. pp. 16-21.

[14] Vercruysse J, Holdsworth P, Letonja P, Barth D, Conder G, Hamamoto K, et al. International harmonization of anthelmintic efficacy guidelines. Vet Parasitol. 2001; 96: pp. 171-93.

[15] Githiori J, Hoglund J, Waller P. Ethnoveterinary plant preparations as livestock dewormers: practices, popular beliefs, pitfalls and prospects for the future. Anim Health Res Rev. 2005; 6(1): 91-103.

[16] Abo K, Lasaki S, Adeyemi A. Laxative and antimicrobial properties of Cassia species growing in Ibadan. Nig. J. Nat. Prod Med. 1999. 3: pp. 47-50.

[17] Sheferaw D, Getachew D, Bekele J, Denbarga Y. Assessment of anthelmintic resistance in gastrointestinal nematodes of small ruminants, Dale district, Southern Ethiopia. J. Vet Med. Anim. Health. 2013. 5(9): pp. 257-61.

[18] Sheferaw D, Asha A. Efficacy of selected anthelmintics against gastrointestinal nematodes of sheep owned by smallholder farmers in Wolaita, Southern Ethiopia. Eth Vet J. 2010; 14(2): pp. 31-8.

[19] Benda K. K., Ampaire A, Komungyeyo J, Mukiibi R, Masembe C, Onzima R. Efficacy of Commercially Available Anthelmintics in Controlling Gastrointestinal Nematodes in Goats Managed Under Natural Conditions in the South Western Highlands of Uganda. American Journal of Clinical and Experimental Medicine. 2015; 3(6): pp. 355-63.

[20] Nsereko G, Emudong P, Magona J, Odoch T, Okwee-Acai J. Anthelmintic efficacy of Albendazole, Levamisole and Ivermectin against gastrointestinal nematode infections in goats on natural pastures in Gomba District, Uganda. Uganda J. Agric. Sci. 2013; 14(1): 75-85.

[21] Abo K, Adeyemi A. Seasonal accumulation of anthraquinones in leaves of cultivated Cassia podocarpa Guill. et Perr. African Journal of Medicinal Science. 2002; 31(2). pp. 171-73.

[22] Harborne JB. Phytochemical Methods, A guide to modern techniques of plant analysis, 1998. 3rd ed. London: Chapman and Hall. 
[23] Deshpande HA and Bhalsing SR. Recent advances in the phytochemistry of some medicinally important Cassia species: A review. Int. J. Pharm. Med. \& Bio. Sc. 2013. Vol. 2, No. 3. pp. 60-78.
[24] Waterman C, Smith RA, Pontiggia L, DerMarderosian A. Anthelmintic screening of Sub-Saharan African plants used in traditional medicine. J. Ethnopharm. 2010. Vol. 127. pp. 755759. 